\title{
Tubular structures of Mycoplasma gallisepticum and their possible participation in cell motility
}

\author{
Eugene V. Korolev, ${ }^{1}$ Andrew V. Nikonov, ${ }^{1}$ Margarita S. Brudnaya, ${ }^{1}$ \\ Ekaterina S. Snigirevskaya, ${ }^{1}$ George V. Sabinin, ${ }^{1}$ Yan Yu. Komissarchik, ${ }^{1}$ \\ Peter I. Ivanov ${ }^{2}$ and Sergei N. Borchsenius ${ }^{1}$
}

\author{
Author for correspondence: Sergei N. Borchsenius. Tel: +7 81224713 13. Fax: +7812 2470341 \\ e-mail: borch@cell.spb.su.
}

1 Institute of Cytology, Russian Academy of Science, Tikhoretsky Avenue, 4, 194064, St Petersburg, Russia

2 Timiryazev Agricultural Academy, Timiryazev Street, 49, 127550, Moscow, Russia

\begin{abstract}
In five strains of Mycoplasma gallisepticum, a protein with a molecular mass of about $\mathbf{4 0} \mathrm{kDa}$ was detected by immunoblotting with anti-pig brain tubulin polyclonal and monoclonal antibodies. In eight other mycoplasma species similarly tested no reaction was observed. Thin serial sections of $M$. gallisepticum and Acholeplasma laidlawii cells examined by transmission electron microscopy revealed a submembrane system of tubules in $\boldsymbol{M}$. gallisepticum but not in A. laidlawii. The intracellular spatial distribution of the tubular structures was reconstructed. Thin sections of $M$. gallisepticum treated with anti-tubulin antibodies and colloidal gold particles (immunogold labelling) revealed distinct labelling of the tubular system. Analysis of the tubular structures by high resolution electron microscopy and optical diffraction showed their helical organization to be: diameter $40 \mathrm{~nm}$, helix pitch approximately $20 \mathrm{~nm}$ and electron-transparent core $10 \mathrm{~nm}$ in diameter. A possible involvement of the tubular system in mycoplasma motility is suggested.
\end{abstract}

Keywords: Mycoplasma gallisepticum, cytoskeleton, tubular structures, motility

\section{INTRODUCTION}

Mycoplasmas lack a cell wall and are amongst the smallest prokaryotes. However, despite the apparent simplicity of their organization, some mycoplasmas (e.g. Mycoplasma gallisepticum, $M$. genitalium, $M$. mobile, $M$. pneumoniae) possess so-called gliding motility, the molecular mechanisms of which are unknown. These motile mycoplasma species have flask- or club-shaped cells with specialized terminal structures ('tips' or 'blebs') which are apparently responsible for movement and adhesion of the mycoplasmas onto host-cell surfaces (Bredt, 1979; Kirchhoff \& Rosengarten, 1984; Kirchhoff, 1992).

Probably, cytoskeletal elements participate in the motility of the non-spheroidal cells, as in eukaryotic cells. In $M$. pneumoniae cells, microfilaments resistant to Triton X-100 were found (Meng \& Pfister, 1980). The possible existence of actin-like proteins as cytoskeletal elements in $M$. gallisepticum and $M$. pneumoniae has been discussed from biochemical (Ghosh et al., 1978; Maniloff \& Chauduri,

Abbreviations : mAb, monoclonal antibody; $\mathrm{pAb}$, polyclonal antibody.
1979), ultrastructural (Collier, 1972; Neimark, 1977), immunological (Göbel, et al., 1981) and DNAhybridization (Chernova et al., 1985; Göbel et al., 1990) viewpoints. But the question of the presence of actin-like proteins in mycoplasmas is not yet clarified.

Tubulin is also a component of the eukaryotic cytoskeleton and is the major protein of microtubules, which participate in chromosome segregation (Simmonds et al., 1983), compartmentalization and intracellular transport of various macromolecules and organelles (Vale et al., 1985; Langford et al., 1987), and in the maintenance of cell form (Kirschner \& Mitchison, 1986). Tubular structures resembling eukaryotic microtubules have been described for several bacteria (for review see Pate, 1988), although the functions of these structures have not been specified. Helical or tetrahedral particulate arrays have also been described in the cytoplasm of $M$. gallisepticum. These were referred to as 'corncob' or 'helical polyribosomes' (Domermuth et al., 1964; Maniloff et al., 1965) and were later analysed by optical diffraction and rotational symmetry techniques (Maniloff, 1971).

In our study, screening of tubulin-like proteins in $M$. 
gallisepticum and eight other mycoplasma species was undertaken using polyclonal and monoclonal antibodies against bovine brain and pig brain tubulins. A system of tubules was revealed and their intracellular spatial distribution reconstructed. The ultrastructural organization of the tubules is discussed.

\section{METHODS}

Organisms and cultivation conditions. A. laidlawii A, $M$. byorbinis BT57, $M$. bominis $\mathrm{H} 34$ and five strains of $M$. gallisepticum (S6, A5969, MR3, U5 and R) were obtained from Dr G. Laber, Sandoz Research Institute, Vienna, Austria; $M$. salivarium $P(520$ and $M$. orale $\mathrm{CH} 19299$ were from Dr K. Jurmanova, Veterinary Institute, Brno, Czechoslovakia; $M$. mycoides subsp. mycoides, $M$. pneumoniae $\mathrm{FH}$ and $M$. fermentans were from Dr I. Rakovskaya, Institute of Epidemiology and Microbiology, Russian Academy of Medical Science, Moscow; and $M$. arginini $\mathrm{R} 16$ was from $\mathrm{Dr}$ V. Berdnik, Zonal Veterinary Station, Poltava, Ukraine. Mycoplasma cultures were grown on Oxoid Mycoplasma Broth Base (Oxoid) supplemented with $20 \%(\mathrm{v} / \mathrm{v})$ preheated horse serum (Flow Laboratories), $10 \%(\mathrm{w} / \mathrm{v})$ fresh yeast extract and $0.1 \%$ arginine (for growth of $M$. salivarium, $M$. hominis, $M$. arginini and $M$. orale) or $0.1 \%$ glucose (for growth of other mycoplasmas) at $37^{\circ} \mathrm{C}$. Organisms were harvested in the exponential phase of growth by centrifugation at $10000 \mathrm{~g}$ for $20 \mathrm{~min}$ and washed three times with phosphate-buffered saline (PBS), $\mathrm{pH} 7 \cdot 2$.

Gel electrophoresis. The washed mycoplasma cells were diluted with PBS to a final concentration of $4 \mu \mathrm{g}$ mycoplasma protein $\mathrm{ml}^{-1}$. Protein content was determined by the method of Bradford (1976) using bovine serum albumin (BSA) as a standard. Equal volumes of sample buffer $(0 \cdot 2 \%$ SDS; $15 \%$, $\mathrm{v} / \mathrm{v}$, glycerol; $10 \mathrm{mM}$ Tris $/ \mathrm{HCl}, \mathrm{pH} 7.5 ; 5 \%, \mathrm{v} / \mathrm{v}, \beta-$ mercaptoethanol) were added to mycoplasma suspensions. Samples were heated for $5 \mathrm{~min}$ at $100^{\circ} \mathrm{C}$. Gel electrophoresis of proteins was carried out on $12 \%(\mathrm{w} / \mathrm{v}$ ) polyacrylamide gel, containing $0 \cdot 1 \%$ SDS, by the method of Laemmli (1970). The molecular masses of the mycoplasma proteins were estimated relative to the electrophoretic mobility of low molecular mass markers (Pharmacia).

Immunoblotting. Electrotransfer of the proteins from the gel to nitrocellulose sheets was carried out by a standard method (Anderson \& Thorpe, 1980). After transfer, the blots were soaked for $30 \mathrm{~min}$ at $20^{\circ} \mathrm{C}$ in $0.1 \%$ Tween-20 in PBS (PBS-Tw). For immunological detection, the blots were incubated for $1 \mathrm{~h}$ at $20^{\circ} \mathrm{C}$ with monoclonal $(1: 2000)$ or polyclonal $(1: 300)$ antibodies (mAbs, pAbs) against tubulin, diluted in PBS-Tw. The blots were then washed three times for $10 \mathrm{~min}$ in PBS-' $\mathrm{Ww}$ and incubated for $1 \mathrm{~h}$ at $20^{\circ} \mathrm{C}$ with peroxidase-conjugated goat anti-rabbit IgG (GAR-peroxidase) or peroxidase-conjugated rabbit anti-mouse IgG (RAM-peroxidase) used at a $1: 2000$ dilution in PBS-Tw. The blots were subsequently washed as described above and soaked at room temperature in the buffer containing $50 \mathrm{mM}$ Tris $/ \mathrm{HCl}(\mathrm{pH} \mathrm{7.5)}, 0.05 \%$ Tween-20, $1 \mathrm{mg}$ $3,3^{\prime}$-diaminobenzidine. $4 \mathrm{HCl}(\mathrm{DAB}) \mathrm{ml}^{-1}$ and $0.0001 \% \mathrm{H}_{2} \mathrm{O}_{2}$.

The mouse mAb TU-01 raised against pig brain tubulin was obtained from Dr V. Viklicky, Institute of Molecular Genetics, Prague, Czechoslovakia. Purified anti-bovine brain tubulin pAbs were from Dr V. Gelfandt, Institute of Protein, Russian Academy of Science, Moscow, Russia. Anti-chicken $\alpha$-tubulin mAbs (Amersham) were also used.

Preparation of mycoplasma cells for electron microscopy. (i) Standard protocol. Mycoplasma cells were grown, harvested, washed as described above and fixed for $20 \mathrm{~min}$ at $20^{\circ} \mathrm{C}$ in $2.5 \%$ $(\mathrm{v} / \mathrm{v})$ glutaraldehyde in PBS. Post-fixation was carried out in $1 \%(\mathrm{w} / \mathrm{v}) \mathrm{OsO}_{4}$ in $\mathrm{PBS}$. Fixed cells were dehydrated in ethanol of ascending concentration (from $50 \%$ to absolute) and embedded in a mixture of Araldite-Epon (Fluka) in the volume ratio Araldite $\mathrm{M}:$ Epon 812:DDSA:DMP, 1:1·6:3.6:0.06. Embedding and polymerization was carried out by incubating specimens for $6 \mathrm{~h}$ at $37^{\circ} \mathrm{C}$ followed by incubation for $12 \mathrm{~h}$ at $45^{\circ} \mathrm{C}$ and $24 \mathrm{~h}$ at $60^{\circ} \mathrm{C}$. Thin sections were cut with a glass knife on an Ultramicrotome (LKB-III) and placed on formvar-coated cuprum grids. The sections were counterstained with uranyl acetate and lead citrate, and examined under JEM 100 and Hitachi H500 electron microscopes.

(ii) Freeze-substitution. Following prefixation with glutaraldehyde a pellet of mycoplasma cells was placed in an envelope made of aluminium foil, $10 \mu \mathrm{m}$ thick. The envelope was dipped into liquid Freon-13 at $-175^{\circ} \mathrm{C}$, transferred into absolute ethanol then cooled to $-100^{\circ} \mathrm{C}$. Substitution of water for ethanol was carried out over $5 \mathrm{~d}$ at $-95 \pm 2{ }^{\circ} \mathrm{C}$ in a homemade cryostat. Then the temperature was slowly raised to $25^{\circ} \mathrm{C}$ and the pellet was embedded in Araldite-Epon. The polymerization, cutting and staining were performed as described above.

(iii) Immunogold labelling of thin sections. Mycoplasma cells were grown, harvested and washed as described above and fixed in PBS containing $4 \%(\mathrm{w} / \mathrm{v})$ paraformaldehyde and $0.2 \%$ glutaraldehyde, $\mathrm{pH} 7 \cdot 2$. The fixed cells were washed in PBS and incubated overnight in $100 \mathrm{mM}$ glycine in PBS at $4{ }^{\circ} \mathrm{C}$. The cells were gradually dehydrated in $30 \%(\mathrm{v} / \mathrm{v})$ ethanol for $30 \mathrm{~min}$ at $4{ }^{\circ} \mathrm{C}, 50 \%$ and $70 \%$ ethanol for $30 \mathrm{~min}$ at $-10{ }^{\circ} \mathrm{C}, 96 \%$ and absolute ethanol for $30 \mathrm{~min}$ at $-30^{\circ} \mathrm{C}$. The dehydrated cells were embedded and incubated in the mixtures of Lowicryl K4M and absolute ethanol with an ascending concentration of Lowicryl (from 30 to $100 \%$ ) at $-30^{\circ} \mathrm{C}$. The cells were incubated overnight in $100 \%$ Lowicryl at $-30{ }^{\circ} \mathrm{C}$. Polymerization of Lowicryl was carried out by UV irradiation for $48 \mathrm{~h}$ at $-34^{\circ} \mathrm{C}$ with additional UV irradiation for $24 \mathrm{~h}$ at $20^{\circ} \mathrm{C}$. Thin sections were cut with a glass knife and mounted on formvar-covered nickel grids. The non-specific reactions in the sections were blocked with $0.5 \%$ BSA in PBS (PBS-BSA) for $30 \mathrm{~min}$ at $20^{\circ} \mathrm{C}$ and incubations with the primary antibody diluted 1:10 for pAbs or 1:50 for mAbs in PBS-BSA were for $1 \mathrm{~h}$ at $20^{\circ} \mathrm{C}$. Grids were washed with PBS-BSA and incubated in the appropriate secondary antibodies (conjugate of $5 \mathrm{~nm}$ colloidal gold and goat anti-rabbit IgG (Sigma) or rabbit antimouse IgG) diluted 1:50 in PBS-BSA for $1 \mathrm{~h}$ at $20^{\circ} \mathrm{C}$. The sections were counterstained with aqueous uranyl acetate and lead citrate, or with $1.8 \%$ aqueous uranyl acetate and $0.2 \%$ methylcellulose (Roth et al., 1990), and examined under the transmission electron microscope. Specificity of immunolabelling was controlled by excluding primary antibodies or by substituting them with non-immune sera.

Optical diffraction. Optical transforms were made from negatives of electron micrographs $(\times 4200)$. To improve the signal-background ratio, only part of the picture (a circle $0.4 \mathrm{~mm}$ diam.) restricted by a diaphragm was analysed.

Analysis was conducted using an optical diffractometer (ИФ124, Russia). A high-power argon laser (ЛГН-402, Russia), operating in a one-mode regime with a wavelength of $0.488 \mu \mathrm{m}$ with a beam delivering $1.5 \mathrm{~W}$ was used as a source of light.

The diffraction pattern was analysed using the theoretical method developed for a general case of X-ray diffraction from discontinuous $\alpha$-helices based on the Bessel function (Cochran $e t$ al., 1952). In our application of this method to the interpretation of diffraction patterns of plane electron micrographs, the 
(a)

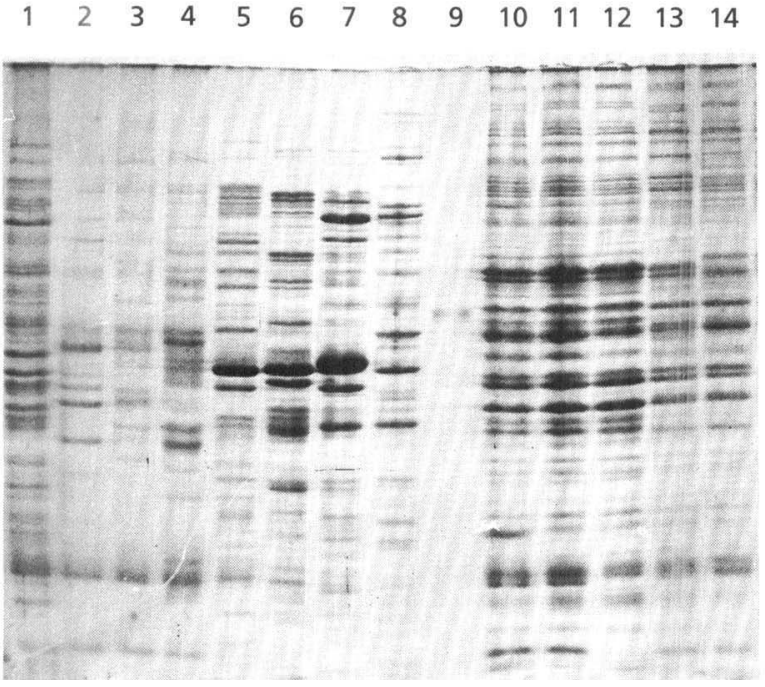

(b)

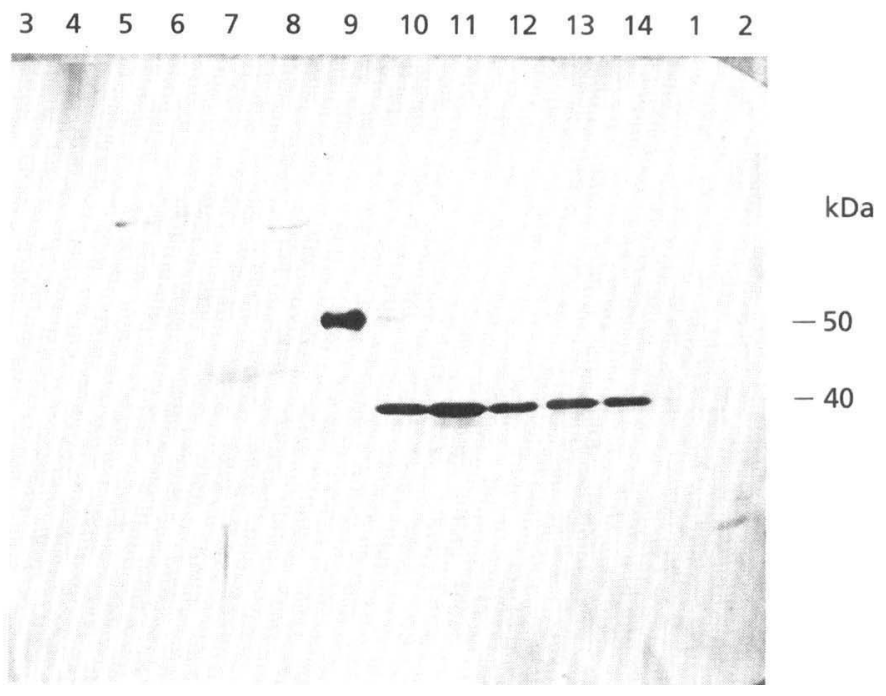

Fig. 1. Identification of $40 \mathrm{kDa}$ tubulin-like protein in $M$. gallisepticum. (a) PAGE of proteins of mycoplasmas $A$. laidlawii A (lane 1), $M$. fermentans (2), M. hyorhinis BTS7 (3), M. mycoides subsp. mycoides (4), M. arginini R16 (5), M. hominis H34 (6), M. orale CH19299 (7), M. salivarium PG20 (8), calf brain tubulin (9) and M. gallisepticum S6, A5969, R, MR3 and U5 (10-14, respectively). The gel is stained with Coomassie blue R-250. (b) Immunoblot of the same material with anti-pig brain $\alpha$-tubulin mAb TU-01 stained with RAM-peroxidase.

principal equations, given in the paper cited were transformed to:

$$
T\left(R, \frac{n}{P}\right)=J_{j}(2 \pi R r)
$$

where $T$ is the Fourier transform for the elementary unit of the helix, $J_{\mathrm{j}}$ is the $\mathrm{jth}$-order Bessel function, $n$ is an integer, $P$ is the helix pitch, $R$ is the helix radius and $r$ is the helix radius in a reciprocal space. When function (1) is expanded in the Fourier series, we obtain:

$$
F\left(R, \frac{n}{P}+\frac{m}{P}\right)=\sum T\left(R, \frac{n}{P}+\frac{m}{P}\right),
$$

where $m$ is an integer, $p$ is the helix period and $F$ is a structural factor, which corresponds to the intensity of diffraction maxima as $I=\left|F^{2}\right|$.

\section{RESULTS}

\section{Immunoblotting of mycoplasma proteins with antibodies to eukaryotic tubulin}

The results of immunoblotting all extracts of five $M$. gallisepticum strains (S6, A5969, MR3, U5, R) and eight other mycoplasma species ( $M$. bominis, $M$. orale, $M$. salivarium, $A$. laidlawii, $M$. fermentans, $M$. byorbinis, $M$. arginini, $M$. mycoides subsp. mycoides) with monoclonal TU01 anti-pig brain $\alpha$-tubulin antibody are given in Fig. 1. All M. gallisepticum strains reacted positively with $\mathrm{mAbs}$, whereas the other eight mycoplasma species gave negative results.

The $40 \mathrm{kDa} M$. gallisepticum protein possessing epitopes

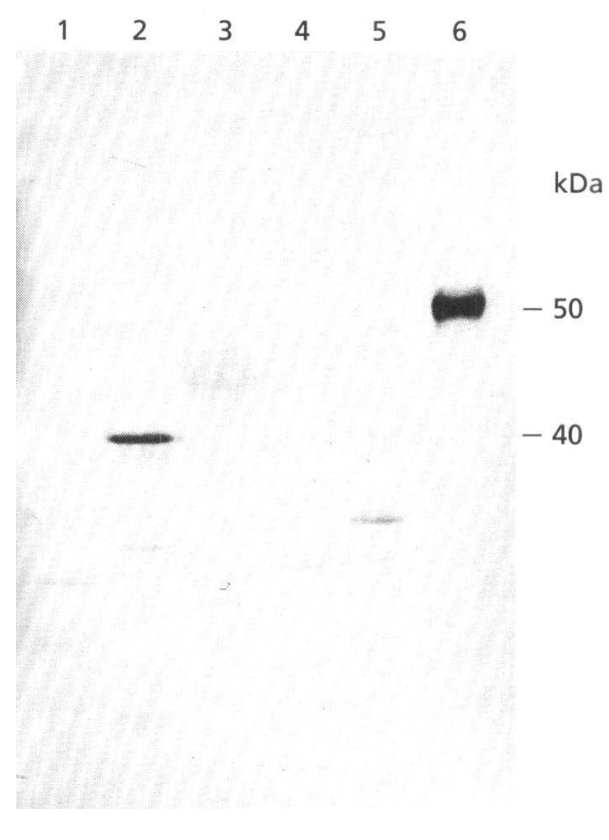

Fig. 2. Immunoblotting of proteins of $A$. laidlawii $A$ (lane 1), $M$. gallisepticum A5969 (2), M. arginini R16 (3), M. fermentans (4), $M$. pneumoniae $\mathrm{FH}(5)$ and calf brain tubulin (6) with antibovine brain $\alpha$-tubulin pAbs, stained with RAM-peroxidase.

similar to eukaryotic $\alpha$-tubulin, is referred to hereafter as tubulin-like protein. These results were confirmed by similar experiments with purified anti-bovine brain tubulin pAbs (Fig. 2) and anti-chicken $\alpha$-tubulin mAbs 


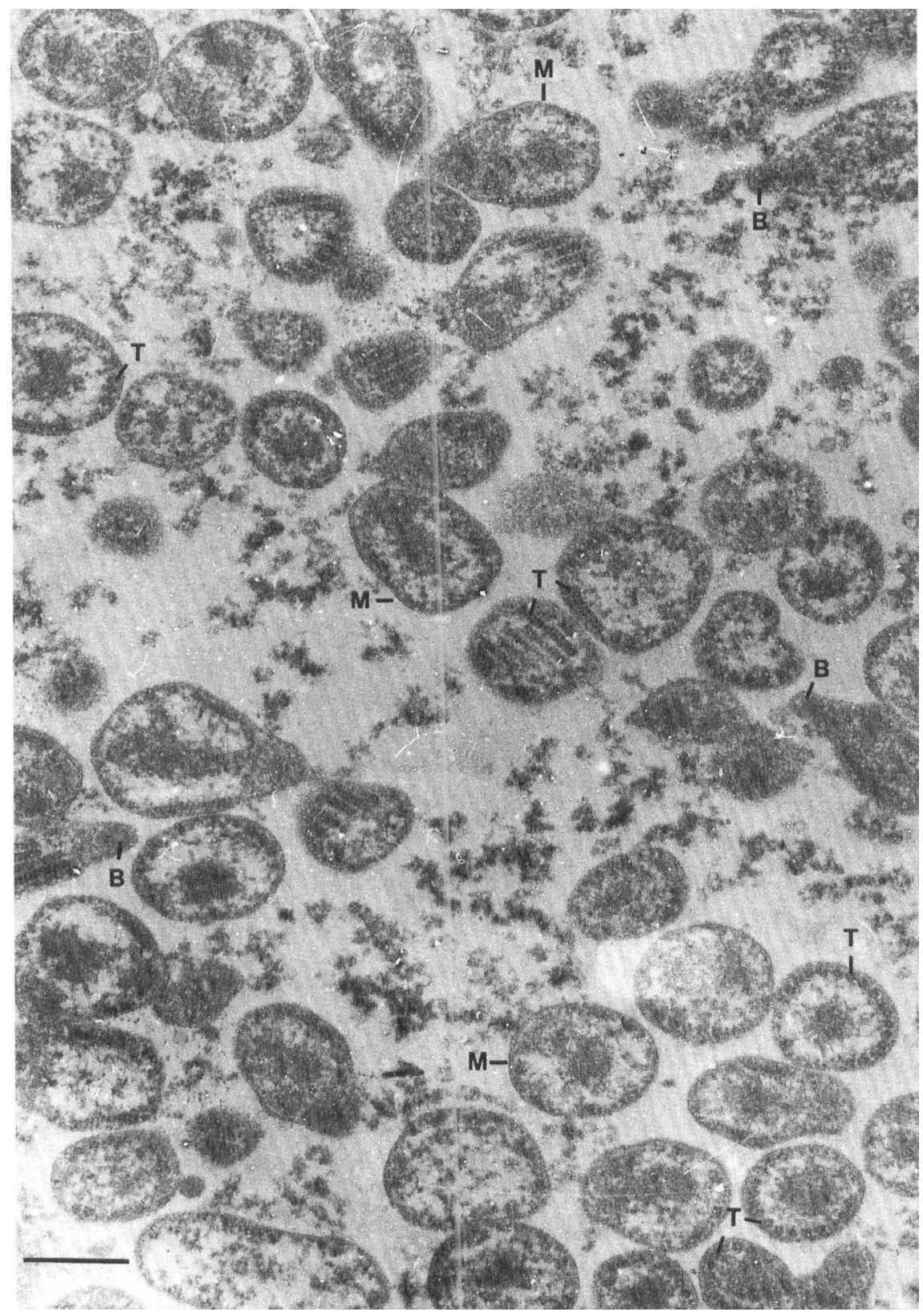

Fig. 3. Thin section of $M$. gallisepticum A5969 cells cut at different angles to the long axis of the cell. M, Cell membrane; $T$, submembrane tubular structure; $B$, specialized terminal structure (bleb). Bar, $0.5 \mu \mathrm{m}$.

(data not shown). M. pneumoniae $\mathrm{FH}$, a motile strain, was also examined.

\section{Electron-microscopic investigations of thin sections}

These were carried out on two $M$. gallisepticum strains (S6 and A5969) and one A. laidlawii strain (A). Fig. 3 shows the profiles of $M$. gallisepticum cells differently oriented from the section plane; most of the profiles appear circular or ovoid. In Fig. 3, electron-dense areas are visible in the region of the specialized terminal structure (bleb) and in the central part of the cytoplasm. In submembrane regions of the cytoplasm, sectioned tubules are revealed. Their fine structure can be seen in cell sections made at different angles and on serial sections (Figs 4, 5). Fig. 4 shows various profiles of tubular structures apposed to the cell membrane. The major parameters of these structures can be determined from the electron micrographs presented. Some profiles show 4-5 electron-dense units encircling an electron-transparent core $10 \mathrm{~nm}$ in diameter. These electron dense units seem to be helicoidally arranged. The helix possibly consists of a continuous line of units, which in most longitudinal profiles of the tubular structures seem to be elongated 

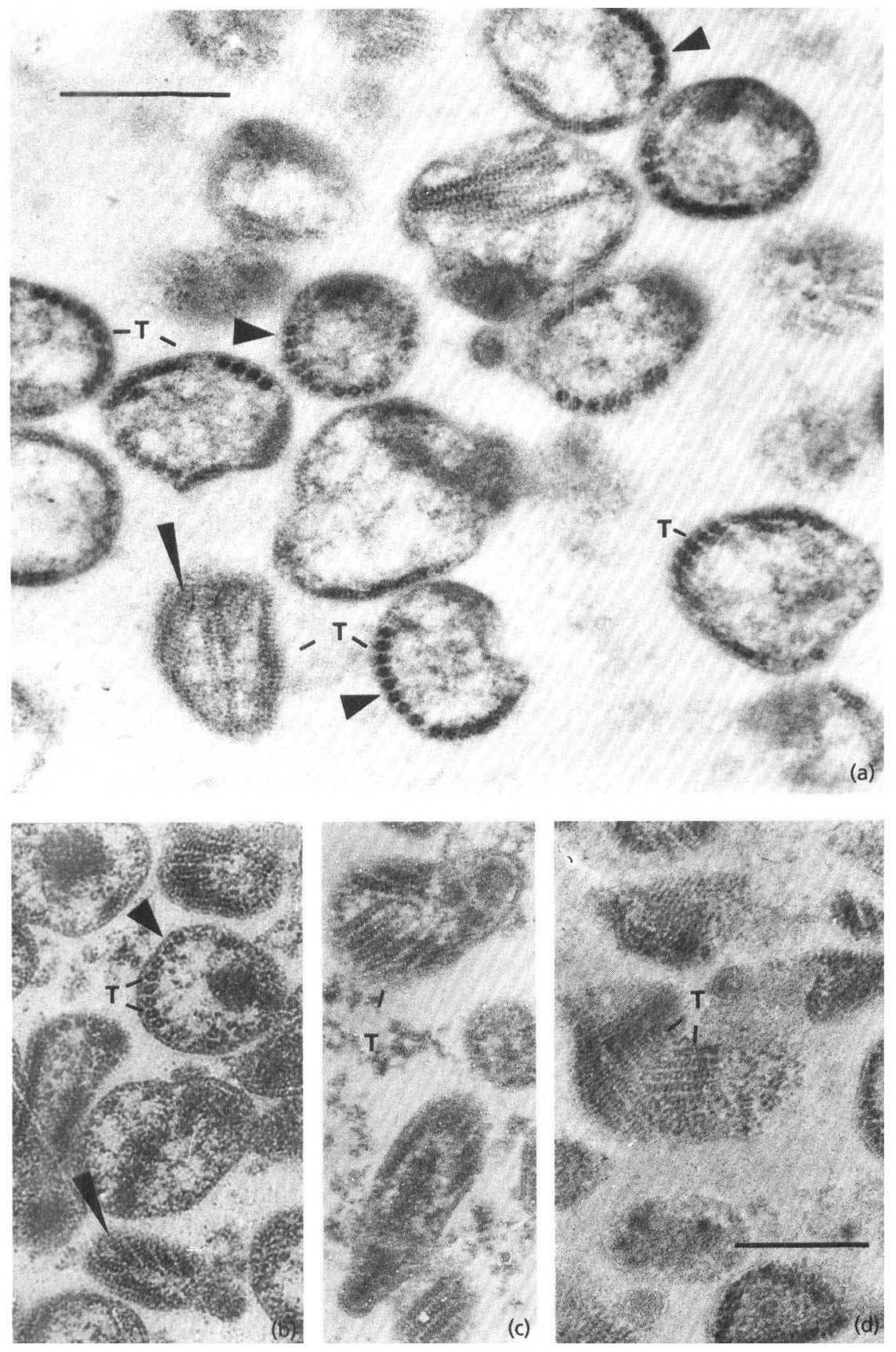

Fig. 4. Elements of the tubular system of $M$. gallisepticum A5969. Tubules (T) are distributed along the membrane of the cell. Up to 4-5 units are revealed in cross-section (short arrowheads in $a$ and b); longitudinal profiles of tubule units appear elongated (long arrowheads in $a$ and b). The tubules diverging from the infrableb area can be seen in (c). Tubules are located in the 'back' region of the cell in (d). Bars, $0.5 \mu \mathrm{m}$.
(Fig. 4). The pitch of the helix is $23 \mathrm{~nm}$, measured using $5 \mathrm{~nm}$ colloidal gold particles as marker.

\section{Parameters of the tubular structure, measured by optical diffraction}

The optical diffraction pattern made from an electron micrograph (Fig. 6a) of a cluster of tubules is shown in Fig. 6b. The optical transform is undoubtedly of a helix. Four meridional layer-lines (reflexes) of the transform correspond to a period of $82 \mathrm{~nm}$. On a vertical axis of the transform another reflex (M) has been detected, which corresponds to the helix pitch of the structure examined (Fig. 6b). The assignments of the layer-lines and their spacing, both observed and calculated, are listed in Table 1.

The distance from the vertical axis to position (E) of meridional layer-lines is determined by the distance between the axis of neighbouring helices (helix-to-helix distance). This distance can be measured directly on the electron micrograph (Fig. 6a). All these parameters are given in Table 2.

As follows from the theory (see Methods), it is possible on the transform to detect the reflexes corresponding to helix pitch $(P)$ and period $(p)$. According to our measurements, helix pitch $(P)$ is 21 (or 23) $\mathrm{nm}$, and helix period $(p)$ is 82 (or 83 ) $\mathrm{nm}$ (see Tables 1,2 ). The $P / p$ ratio is 3.9 or 3.6 , 


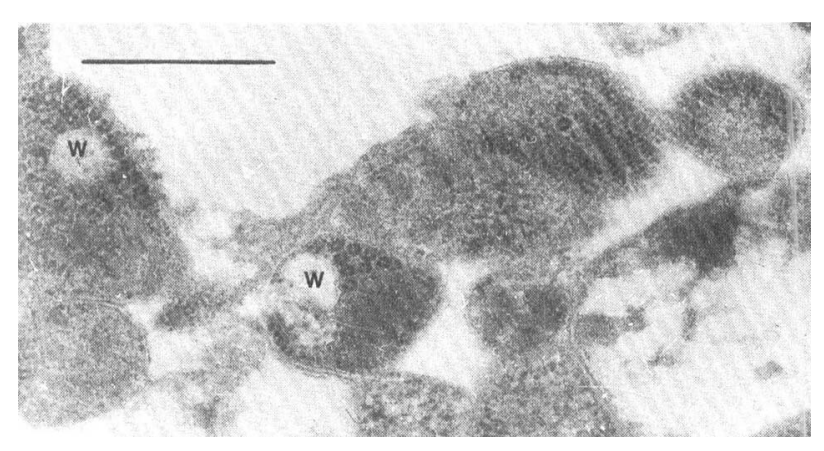

Fig. 5. Thin sections of $M$. gallisepticum A5969 cells prepared by the freeze-substitution method. Some cross-sectioned profiles of the tubules with 4-5 globules are pressed back from the submembrane position by ice crystals $(W)$. Bar, $0.5 \mu \mathrm{m}$.

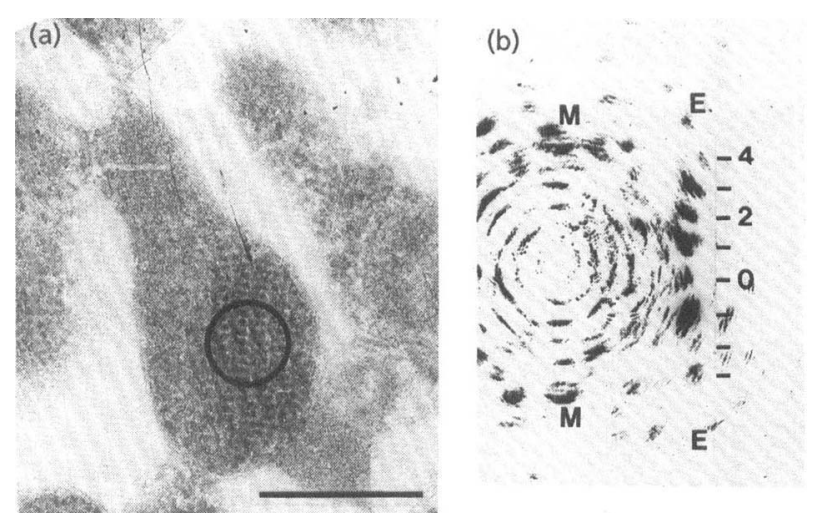

Fig. 6. Optical diffraction. (a) Electron micrograph (thin section) of a $M$. gallisepticum cell. Encircled is a cluster of tubular structures. Bar, $0.5 \mu \mathrm{m}$. (b) Optical transform (diffraction pattern) of the region limited by the circle shown in (a). The figures on the righthand side of the picture show the layer-line (reflexes) assignment. $M$, basic meridional reflex; $E$, location of equatorial reflexes.

Table 1. Layer-line spacing (meridional reflexes) of the optical transform in Fig. 6(b)

\begin{tabular}{|ccc|}
\hline \multirow{2}{*}{$\begin{array}{c}\text { Layer-line } \\
\text { assignment }\end{array}$} & \multicolumn{2}{c|}{ Spacing (nm) } \\
\cline { 2 - 3 } & Observed & $\begin{array}{c}\text { Calculated } \\
\text { (for 83 nm repeat) }\end{array}$ \\
\hline 1 & 82 & 83 \\
2 & 38 & 41 \\
3 & 28 & 28 \\
4 & 22 & 21 \\
\hline
\end{tabular}

respectively. The last figure is more correct, in our opinion, if one takes the distortion seen in the diffractogram (Fig. 6b) into account.
Table 2. Helix measurements

\begin{tabular}{|lcc|}
\hline Parameters & $\begin{array}{c}\text { Determined } \\
\text { by optical } \\
\text { diffraction } \\
\text { (nm) }\end{array}$ & $\begin{array}{c}\text { Measured on } \\
\text { electron } \\
\text { micrographs } \\
\text { (nm) }\end{array}$ \\
\hline Helix pitch & 21 & 23 \\
Helix-to-helix distance & 39 & 42 \\
Helix diameter & - & 41 \\
\hline
\end{tabular}

If $P / p$ is an integer, on a discontinuous helix, there will be periods different from the helix pitch. According to our data, the $P / P$ ratio is a non-integer, indicating the absence of such periods. These data possibly reflect the superposition of Bessel functions from the cluster of helices located in close proximity to one another.

\section{Spatial distribution of the tubular system}

The examination of sections of cells made at different angles (Figs 3-5) makes it possible to propose a model of spatial distribution of the tubular system inside the $M$. gallisepticum cell. To confirm this idea of the spatial organization of the tubules, serial sections were made. The thickness of the sections was $40-70 \mathrm{~nm}$. The average diameter of $M$. gallisepticum cells is approximately $500 \mathrm{~nm}$. Three of six serial sections across cells $A$ and $B$, are shown in Fig. 7. These three sections make reconstruction of the spatial distribution of the tubular system possible (Figs 8 , 9).

From analysis of the electron micrographs, the tubules appear loop-shaped. They are not visible in the bleb and infrableb areas. Nevertheless, both ends of the tubules are located close to the infrableb. Cell size varies, as well as the number, shape and position of tubular loops. The outline of the infrableb area also probably undergoes changes during the cell division cycle. The scheme depicted in Fig. 8 is based on examination of numerous electron micrographs.

The tubular structures were also detected in their cross profiles (rings of 4-5 electron dense units) or longitudinal profiles on sections prepared by freeze-substitution of $M$. gallisepticum cells (Fig. 5a, b). Even at the high speed of freezing, the possibility of water crystallization inside some of the cells cannot be excluded. Crystals of ice are visualized on sections as electron-lucent regions, differing in shape and size. It looks as if the natural spatial distribution of tubules was perturbed during ice formation. As a result, tubules were pressed back from the submembrane position to the central part of the cell (Fig. 5a), thus suggesting that the tubular structures had been present in the native cell prior to freezing.

The tubular system in each strain of $M$. gallisepticum (S6 and A5969) was morphologically identical. However, in A. laidlawii cells treated simultaneously by the same methods of fixation and embedding, such a system was not found. The tubular structures detected in all the 


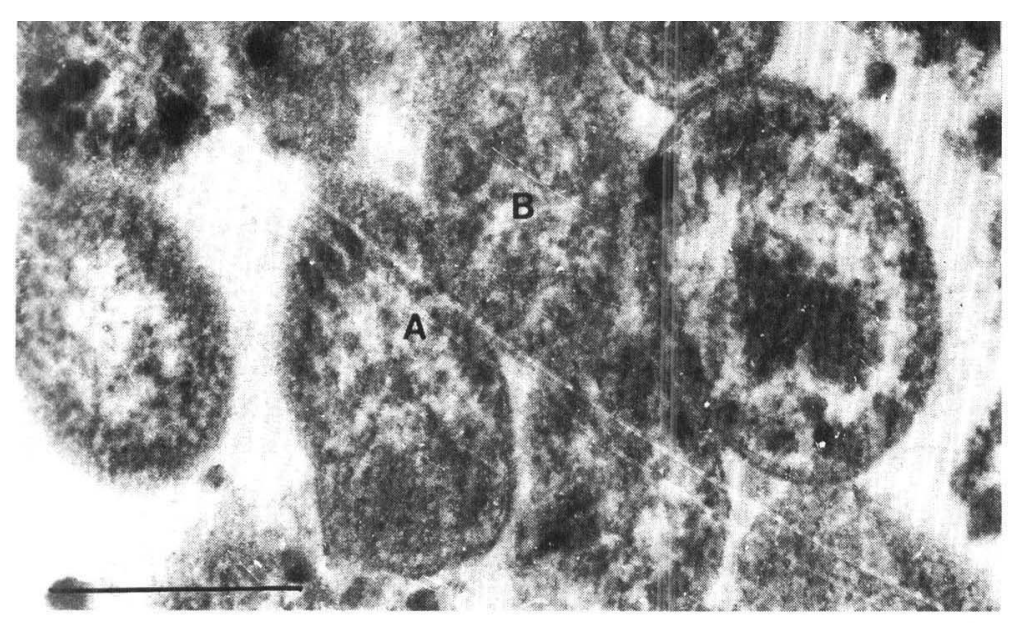

Section 5

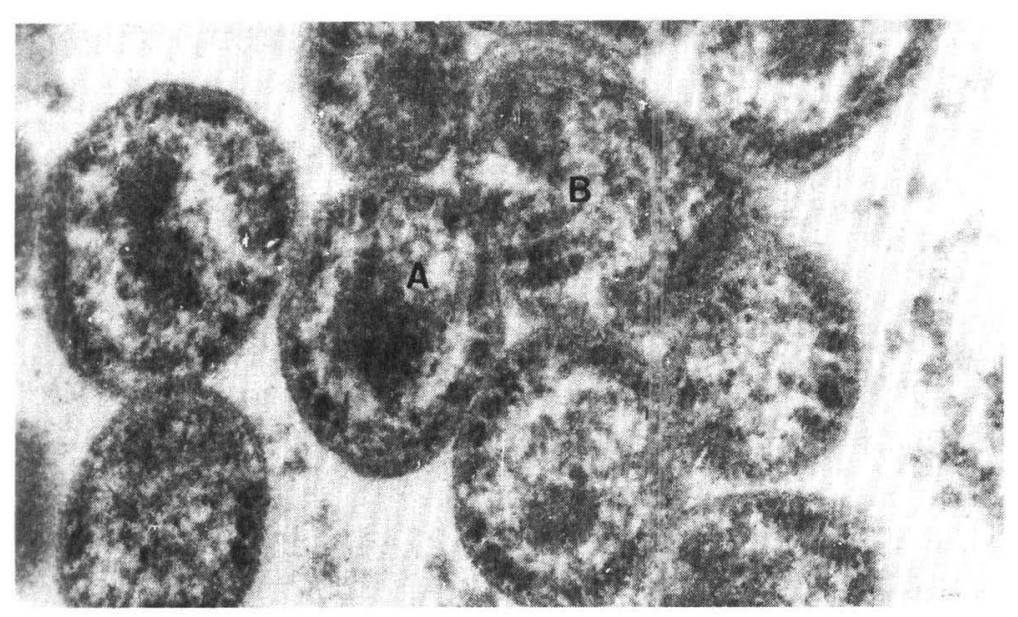

Section 2

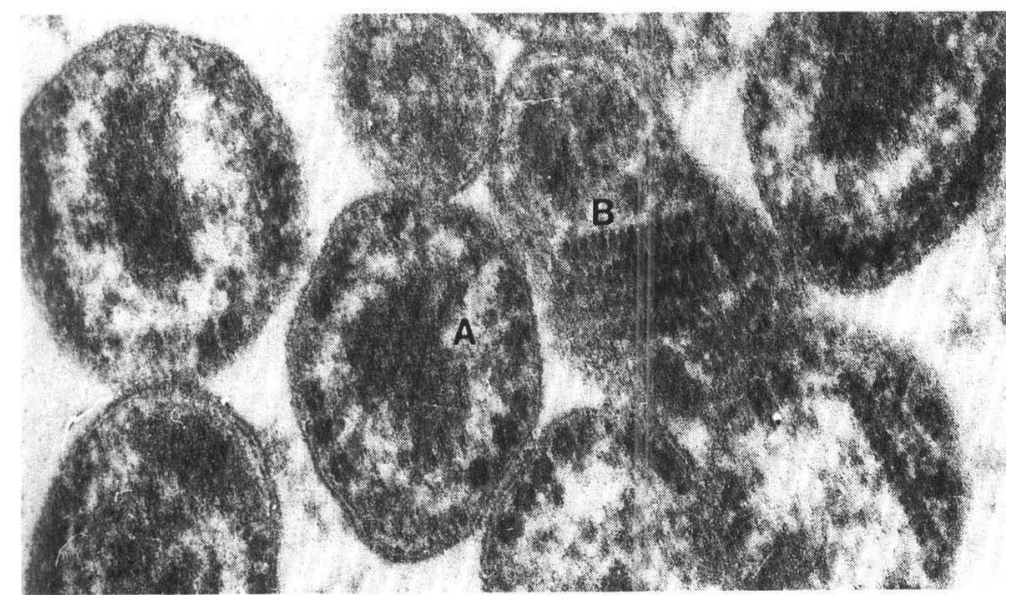

Section 1
Fig. 7. Three sections (1,2 and 5) from serial sections of $M$. gallisepticum A5969 cells. Spatial distribution of the tubular system can be followed on two cells (A, B). In cell A the transfer from cross-cut to longitudinal profiles of loop-shaped tubules is seen. In cell $B$ different regions of cross-sectioned tubules are visible. Bar, $0.5 \mu \mathrm{m}$. 

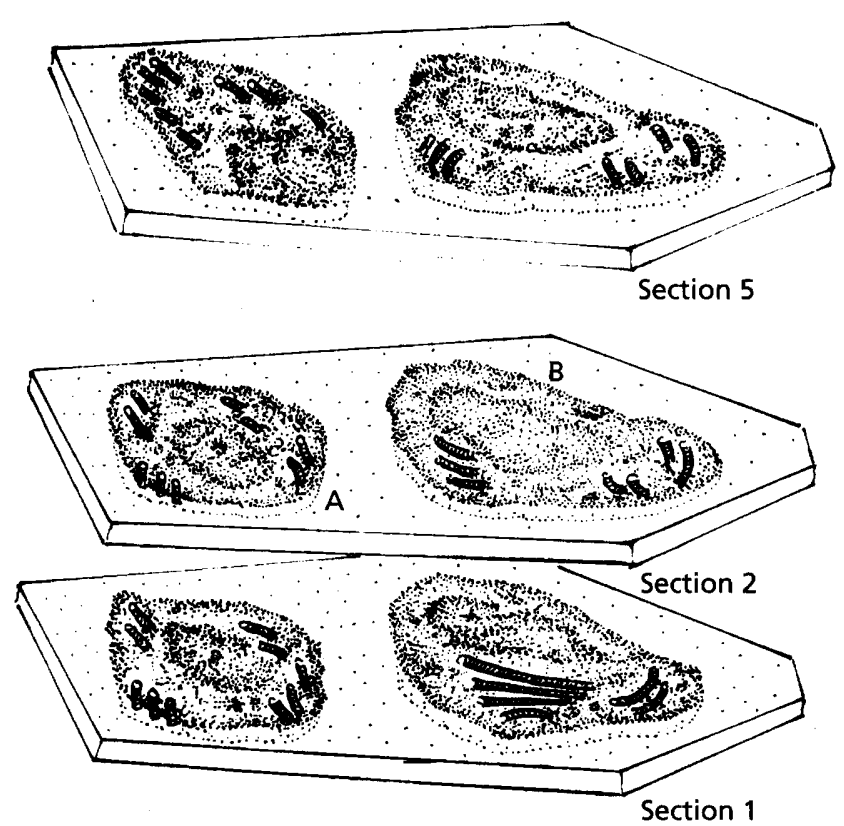

Fig. 8. Schematic interpretation of sections 1, 2 and 5 shown in Fig. 7.

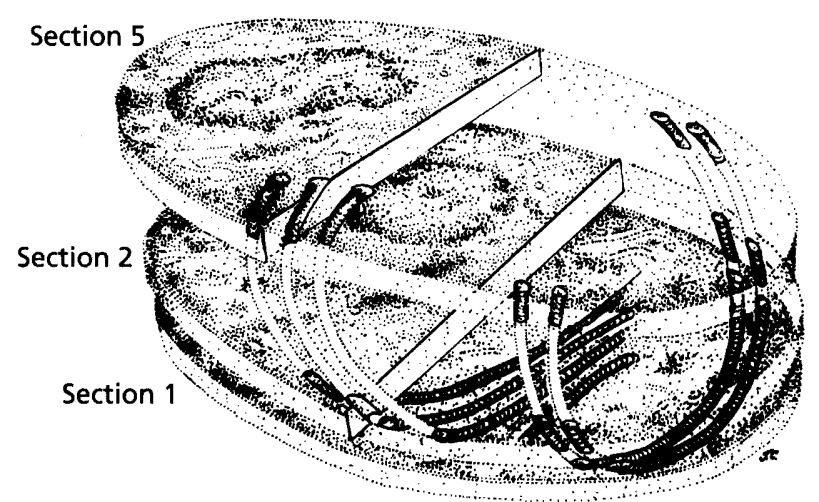

Fig. 9. Partial reconstruction of the tubular system of $M$. gallisepticum (cell B) based on a series of sections (1, 2 and 5) shown in Figs 7 and 8.

samples of $M$. gallisepticum cells fixed and embedded in Araldite or Lowicryl were similar.

\section{Immunogold labelling of thin sections}

To compare the immunoblotting data with ultrastructura! observations, electron microscopy was carried out using: immunogold labelling of anti-tubulin antibodies. Colloidal gold particles found over the tubular structures, using pAbs against bovine brain tubulin (Fig. 10a-c) and mAbs against chicken $\alpha$-tubulin, usually gave similar results (Fig. 10d). Gold particles are aligned on the longitudinal sections of the tubules (Fig. 10a). In Fig. $10(\mathrm{~b}, \mathrm{c})$, gold particles are also visible in the profiles of cross-sectioned tubules. The labelling is distinctly visible in the infrableb area as well. It should be pointed out that the density of colloidal gold labelling is much lower when $\mathrm{mAbs}$ are used. These results, together with negative results of the control experiments without primary antibodies or using non-immune sera as a substitute, enable us to conclude that the binding of colloidal gold particles to the tubular structures is specific.

\section{DISCUSSION}

A protein detected in $M$. gallisepticum has common epitopes with bovine and pig brain tubulins. The molecular mass of this protein, determined by electrophoretic mobility, was about $40 \mathrm{kDa}$ and differed from that of bovine brain tubulin which is known to be $50 \mathrm{kDa}$ (for review see Burns, 1991).

Specificity of the anti-pig brain tubulin $\mathrm{mAb} \mathrm{Tu}-01$ has been demonstrated in many laboratories, in studies of eukaryotic microtubules (Viklicky et al., 1982; Grimm et al., 1987). Epitopes of $\alpha$-tubulins of different organisms (bull, drosophila, yeasts and many others) recognized by $\mathrm{mAb} \mathrm{Tu}-01$, belong to a more conservative region of the polypeptide chain of tubulins (Little \& Seehaus, 1988).

PAGE of total protein of M. gallisepticum (Fig. 1) shows that the band referred to as tubulin-like protein is one of the major bands in the protein spectrum. Tubulin-like protein was not detected in the other mycoplasma species we studied, including M. mycoides subsp. mycoides, which is non-motile but capable of reversible changes of cell shape (Bredt, 1979), and M. pneumoniae which is motile.

The mycoplasmas showing so-called 'gliding motility' are devoid of flagella or cilia. Thus, the existence of cytoskeletal structures seems to be crucial for mobility, and this possibility has been discussed for more than two decades (for review see Kirchhoff, 1992).

In this study, a system of tubular structures in $M$. gallisepticum has been revealed. It cannot be excluded that the tubular system is unique to $M$. gallisepticum. The intracellular ' rho' structure of M. mycoides (Rodwell $e t$ al., 1975) also appears to be specific.

One may ask why $M$. gallisepticum, the slowest of the gliding mycoplasmas (gliding velocity $0 \cdot 03-0 \cdot 05 \mu \mathrm{m} \mathrm{s}^{-1}$ ), possesses tubulin-like protein and a system of tubules, whereas these structures are absent in the faster-moving $M$. pneumoniae $\left(0 \cdot 3-0.4 \mu \mathrm{m} \mathrm{s}^{-1}\right)$. Similarly, the fastest gliding mycoplasma, M. mobile $\left(2 \cdot 0-4 \cdot 5 \mu \mathrm{m} \mathrm{s}^{-1}\right)$, which has been extensively investigated (Kirchhoff \& Rosengarten, 1984) also lacks tubular structures resembling those of M. gallisepticum. Possibly, motility is a comparatively new development in mycoplasmas which are considerably divergent in an evolutionary sense. The phylogeny of mycoplasmas and peculiarities of their evolution were reviewed recently (Maniloff, 1992).

Tubular structures have been observed previously in $M$. gallisepticum; however, they have been considered as 'ribosomal helices' and their spatial distribution inside the cell has never been studied (Domermuth et al., 1964; Allen et al., 1970; Maniloff, 1971, 1972; Maniloff \& Chauduri, 1979). 

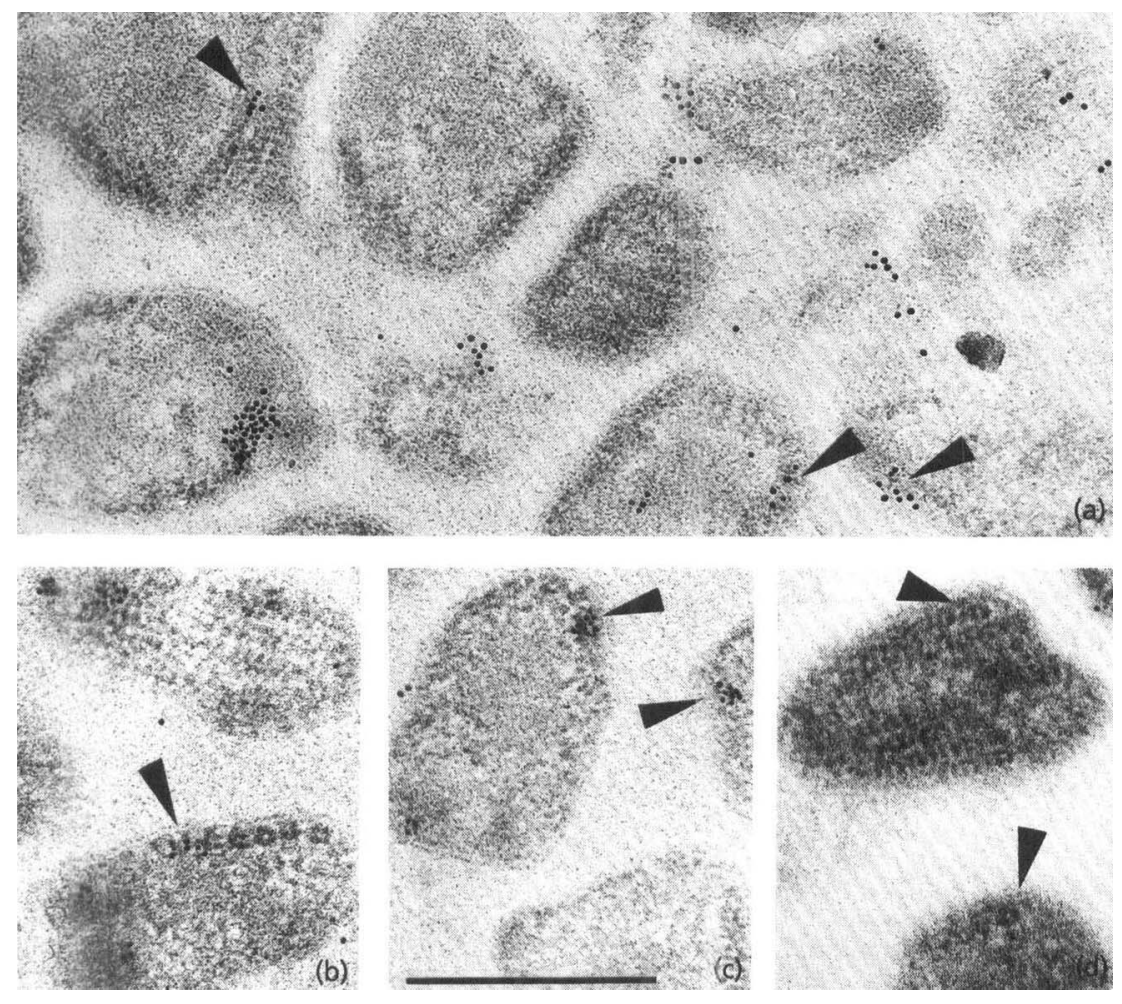

Fig. 10. Immunoelectron microscopy of thin sections of $M$. gallisepticum A5969 cells. $M$. gallisepticum cells labelled with pAbs against calf brain tubulin (a-c) and mAbs against chicken $\alpha$-tubulin (d) as the primary antibodies, and with $5 \mathrm{~nm}$ goat anti-rabbit IgG-colloidal gold or rabbit anti-mouse IgGcolloidal gold, respectively, as the secondary antibodies. Arrowheads indicate gold particles seen on profiles of the tubular structure. The infrableb area or organizing centre of tubules is heavily labelled (a). Bar, $0.5 \mu \mathrm{m}$.

In our control experiments, the tubular structures may be revealed prior to centrifugation of $M$. gallisepticum cells, following fixation directly in growth medium. These data suggest that the tubular system of $M$. gallisepticum is unlikely to be a result of non-physiological conditions of cell treatment, as was shown for spiral structures of E. coli cells treated with vinblastine (Kingsbury \& Voelz, 1969) and spiral structures of $A$. laidlawii enzymes found in cell extracts (Kessel et al., 1981). Tubular structures of $M$. gallisepticum were also detected in freeze-substitution experiments and the results enable us to conclude that they are native subcellular elements.

Our experimental approach to the measurement of the parameters of the tubular structures was similar to that of Maniloff (1971) and the major result obtained was the same: the optical transform of the electron micrograph of the structure was the diffraction pattern of a helix. But according to Maniloff, the $P / p$ ratio was 3.0 (integer value), whereas our analysis of the transform shows that this value is essentially higher (3.6 or 3.9$)$ and noninteger. Therefore, the ribosomal model suggested by Maniloff 23 years ago can hardly be correct. The elongated shape of units on some longitudinal profiles of the tubular structures and the existence of an electron transparent core in cross-sections also seem to disagree with the ribosomal model. In our opinion the structure is definitely helical but the helix is not ribosomal.

It is natural to speculate that the helical tubules are built up from subunits. It remains to be clarified how the electron-dense units seen in cross-sections of the tubular structure correspond to molecules of the tubulin-like protein $(40 \mathrm{kDa}$ ) revealed on protein blots (Figs 1 and 2).
Further studies are necessary to determine the parameters of the subunits of the helical structure.

We are inclined to attribute the helical structures to the elements of the mycoplasma cytoskeleton for the following reasons.

1. Spatial reconstruction of the system of tubular structures (Fig. 11), shows that they are located mainly on the cell periphery and may be represented by smoothly curved loops. Such a system of tubules might perform the function of a cytoskeleton.

2. We assume that, analogous to eukaryotic microtubules (Farrell et al., 1987), the structural polarity of $M$. gallisepticum tubules requires that the two ends of the tubule are different (minus end and plus end). The ends of the tubules are located in the infrableb area forming a tubular 'organizing centre' (Fig. 11). Structural polarity makes it possible for the monomers of tubulin-like protein to associate predominantly at the plus end and to dissociate predominantly at the minus end. By analogy with the 'dynamic instability' of eukaryotic microtubules, monomeric protein molecules could be continually transferred from one end of the tubules to the other (treadmilling process). In this case, the concentration of the monomers of tubulin-like protein should be maximal in the organizing centre (infrableb area). This presumption is in agreement with our data on immunogold labelling, which, in some cases, is most abundant in the infrableb area (Fig. 10a).

3. It is known that some mycoplasma antigens are connected with cytoskeleton elements (Stevens \& Krause, 1991) and it has also been suggested that some antigens 


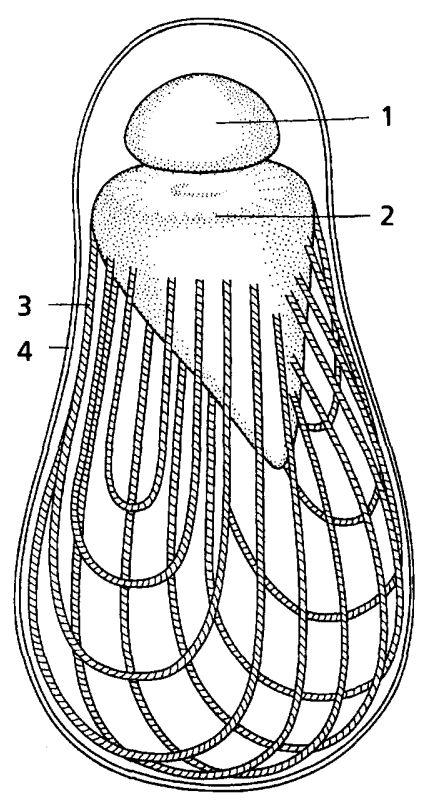

Fig. 11. A hypothetical scheme based on serial sections and on numerous random sections made at different angles to the long axis of the cell. The specialized terminal structure (bleb) (1), the electron-dense area (infrableb) (2), loop-shaped tubules (3) and plasma membrane (4) are shown.

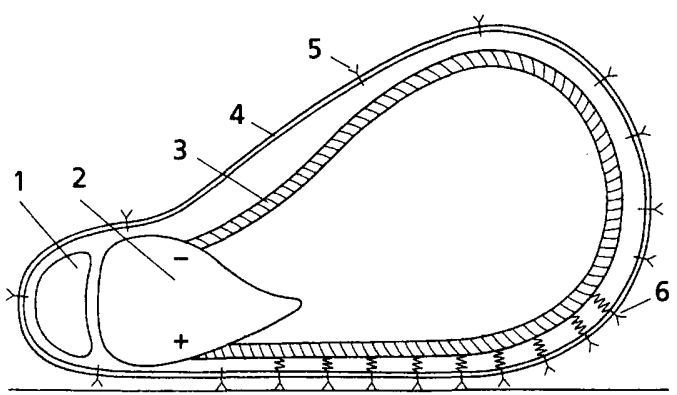

Fig. 12. A scheme of the assumed 'caterpillar' type of mycoplasma cell motility. It can be supposed that due to the attachment (adhesion) of a mycoplasma cell to the solid surface (substrate), conformational changes of surface antigens (5) may take place. These changes may lead to an anchoring of surface antigens (6) in the tubule (3). Treadmilling of the tubule (see the text) ensures the directional movement of antigens along the membrane (4), making the cell move. The bleb (1) and infrableb or organizing centre of tubules (2) form the leading end of the cell. + and - designate the ends of tubules, at which association and dissociation, respectively, occur.

can move along the cell surface (Kahane, 1984). We further speculate that the tubular system found in $M$. gallisepticum cells may exercise a cytoskeletal function by means of reversible anchoring of surface proteins on tubules and directional movement along the mycoplasma surface membrane. We designated this type of mycoplasma cell motility 'caterpillar' movement. This idea is illustrated by Fig. 12. The existence of the connection between tubulin-like protein and surface antigens (ad- hesins) of $M$. gallisepticum has yet to be experimentally determined.

4. An alternative biological role of the tubular system in chromosome segregation cannot be excluded. Such a role, as a primitive mitotic-like apparatus, has already been proposed for the specialized terminal structures (bleb and infrableb) of $M$. gallisepticum (Morowitz \& Maniloff, 1966; Maniloff \& Quinlan, 1974; Ghosh et al., 1978; Raikov, 1985).

The protein revealed in this work has common epitopes with the tubulin of mammals; however, it differs in molecular mass and the electron microscopic parameters of the tubular structures do not correspond to those of classical microtubules. Nevertheless, antibodies to eukaryotic tubulin react not only with a corresponding band on the protein blot of $M$. gallisepticum, but also directly with the tubular structures in immunogold assay. We consider the protein as tubulin-like and suggest a cytoskeletal function of the tubular structures analogous to eukaryotic microtubules.

\section{REFERENCES}

Allen, T. C., Stevens, J. O., Florance, E. R. \& Hampton, R. O. (1970). Ultrastructure of Mycoplasma gallisepticum isolate 1056. J Ultrastruct Res 33, 252-262.

Anderson, B. H. \& Thorpe, R. C. (1980). New methods for analyzing antigens and glycoproteins in complex mixtures. Immunol Today 1 , $122-127$

Bradford, M. M. (1976). A rapid and sensitive method for the quantification of microgram quantities of protein using the principle of protein-dye binding. Anal Biochem 72, 248-254.

Bredt, W. (1979). Motility. In The Mycoplasmas, Vol. 1: Cell Biology, pp. 141-155. Edited by M. F. Barile \& S. Razin. London, New York: Academic Press.

Burns, R. G. (1991). $\alpha$-, $\beta$ - and $\gamma$-tubulins: sequence comparison and structural constraints. Cell Motil Cytoskeleton 20, 181-189.

Chernova, O. A., Merkulova, N. A. \& Borchsenius, S. N. (1985). The detection of the fragments homologous to eukaryotic actin gene in DNAs of mobile mycoplasmas. Biopolim Kletka 3, 312--324 (in Russian).

Cochran, W., Crick, F. H. C. \& Vand, V. (1952). The structure of synthetic polypeptides. 1 . The transform of atoms on a helix. Acta Crystallogr 5, 581-586.

Collier, A. M. (1972). Pathogenesis of Mycoplasma pneumoniae infection as studied in the human foetal trachea in organ culture. In Pathogenic Mycoplasmas, A Ciba Foundation Symposium, pp. 307-319. Amsterdam: Associated Scientific Publishers.

Domermuth, C. H., Nielsen, M. H., Feundt, E. A. \& BirchAndersen, A. (1964). Ultrastructure of mycoplasma species. $J$ Bacteriol 88, 727-744.

Farrell, K. W., Jordan, M. A., Miller, H. P. \& Wilson, L. (1987). Phase dynamics at microtubule ends: the coexistence of microtubule length changes and treadmilling. I Cell Biol 104, 1035-1046.

Ghosh, A., Maniloff, J. \& Gerling, D. A. (1978). Inhibition of mycoplasma cell division by cytochalasin B. Cell 13, 57-64.

Gobel, U. B., Speth, V. \& Bredt, W. (1981). Filamentous structures in adherent Mycoplasma pneumoniae cells treated with nonionic detergents. J Cell Biol 91, 537-543.

Göbel, U. B., Muller, M. M. \& Maas, R. (1990). Actin-related DNA 
sequences and proteins from motile mycoplasmas: a molecular puzzle. In Recent Advances in Mycoplasmology: Baden near Vienna, pp. 337-344. Edited by G. Stanek, G. H. Cassel, J. G. Tully \& R. F. Whitcomb. Stuttgart: Gustav Fischer Verlag.

Grimm, M., Breitling, F. \& Little, M. (1987). Location of the epitope for the $\alpha$-tubulin antibody TU-01. Biochim Biophys Acta 914, 83-88.

Kahane, I. (1984). In vitro studies on the mechanism of adherence and pathogenicity of mycoplasmas. Isr J Med Sci 20, 874-877.

Kessel, M., Peleg, I., Muhlrad, A. \& Kahane, I. (1981). Cytoplasmic helical structure associated with Acholeplasma laidlawii. J Bacteriol 147, 653-659.

Kingsbury, E. W. \& Voelz, H. (1969). Induction of helical arrays of ribosomes by vinblastine sulfate in Escherichia coli. Science 166, 768-769.

Kirchhoff, H. (1992). Motility. In Mycoplasmas. Molecular Biology and Patbogenesis, pp. 289-306. Edited by J. Maniloff. Washington, DC: American Society for Microbiology.

Kirchhoff, H. \& Rosengarten, R. (1984). Isolation of a motile mycoplasma from fish. J Gen Microbiol 130, 2439-2445.

Kirschner, M. \& Mitchison, T. (1986). Beyond self-assembly : from microtubules to morphogenesis. Cell 45, 329-342.

Laemmli, U. K. (1970). Cleavage of structural proteins during the assembly of the head of bacteriophage T4. Nature 227, 680-685.

Langford, G. M., Allen, R. D. \& Weiss, D. G. (1987). Substructure of sidearms on squid axoplasmic vesicles and microtubules visualized by negative contrast electron microscopy. Cell Motil Cytoskeleton 7, 20-30.

Little, M. \& Seehaus, T. (1988). Comparative analysis of tubulin sequences. Comp Biochem Pbysiol 90B, 655-670.

Maniloff, J. (1971). Analysis of the helical ribosome structures of Mycoplasma gallisepticum. Proc Natl Acad Sci USA 68, 43-47.

Maniloff, J. (1972). Cytology of the mycoplasmas. In Pathogenic Mycoplasmas. A Ciba Foundation Symposium, pp. 67-86. Amsterdam: Associated Scientific Publishers.

Maniloff, J. (1992). Phylogeny of mycoplasmas. In Mycoplasmas. Molecular Biology and Pathogenesis, pp. 549-559. Edited by J. Manniloff. Washington, DC: American Society for Microbiology.

Maniloff, J. \& Chauduri, U. (1979). Gliding mycoplasmas are inhibited by cytochalasin B and contain a polymerizable protein fraction. J Supramol Struct 12, 299-304.

Maniloff, J. \& Quinlan, R. J. (1974). Partial purification of a membrane-associated deoxyribonucleic acid complex from Mycoplasma gallisepticum. J. Bacteriol 120, 495-501.

Maniloff, J., Morowitz, H. J. \& Barrnett, R. J. (1965). Ultrastructure and ribosomes of Mycoplasma gallisepticum. J Bacteriol 90, 193-204.

Meng, K. E. \& Pfister, R. M. (1980). Intercellular structures of Mycoplasma pneumoniae revealed after membrane removal. J. Bacteriol 144, 390-399.

Morowitz, H. J. \& Maniloff, J. (1966). Analysis of the life cycle of Mycoplasma gallisepticum. J Bacteriol 91, 1638-1644.

Neimark, H. (1977). Extraction of an actin-like protein from the prokaryote Mycoplasma pneumoniae. Proc Natl Acad Sci USA 74, 4041-4045.

Pate, J. L. (1988). Gliding motility in prokaryotic cells. Can $J$ Microbiol 88, 459-465.

Raikov, I. B. (1985). Primitive never-dividing macronuclei of some lower ciliates. Int Rev Cytol 95, 267-325.

Rodwell, A. W., Peterson, J. E. \& Rodwell, E. S. (1975). Striated fibers of the rho form of mycoplasma. In vitro reassembly composition and structure. J Bacteriol 122, 1216-1229.

Roth, J., Taatjes, D. J. \& Toruyasu, K. T. (1990). Contrasting of lowicryl K4M thin sections. Histochemistry 95, 123-136.

Simmonds, D., Setterfield, G. \& Brown, D. L. (1983). Organization of microtubules in dividing and elongating cells of Vicia bajastana Grossh. in suspension culture. Eur J Cell Biol 32, 59-66.

Stevens, M. K. \& Krause, D. C. (1991). Localization of the Mycoplasma pneumoniae cytadherence-accessory proteins HMW1 and HMW4 in the cytoskeleton-like triton shell. J Bacteriol 173, 1041-1050.

Vale, R. D., Schnaap, B. J., Reese, T. S. \& Sheetz, M. P. (1985). Organelle, bead, and microtubule translocations promoted by soluble factors from the squid giant axon. Cell 40, 559-569.

Viklicky, V., Draber, P., Hesek, J. \& Bartek, J. (1982). Production and characterization of a monoclonal antitubulin antibody (TU-01). Cell Biol Int Rep 6, 725-731.

Received 6 August 1993; accepted 23 September 1993. 